\title{
Article \\ Selection Process of a Mixed Inoculum of Non-Saccharomyces Yeasts Isolated in the D.O.Ca. Rioja
}

\author{
Rocío Escribano-Viana (D), Lucía González-Arenzana (D), Patrocinio Garijo, Rosa López, Pilar Santamaría \\ and Ana Rosa Gutiérrez *
}

Citation: Escribano-Viana, R.; González-Arenzana, L.; Garijo, P.; López, R.; Santamaría, P.; Gutiérrez, A.R. Selection Process of a Mixed Inoculum of Non-Saccharomyces Yeasts Isolated in the D.O.Ca. Rioja. Fermentation 2021, 7, 148. https:// doi.org/10.3390/fermentation7030148

Academic Editor: Antonio Morata

Received: 29 June 2021

Accepted: 7 August 2021

Published: 10 August 2021

Publisher's Note: MDPI stays neutral with regard to jurisdictional claims in published maps and institutional affiliations.

Copyright: (c) 2021 by the authors. Licensee MDPI, Basel, Switzerland. This article is an open access article distributed under the terms and conditions of the Creative Commons Attribution (CC BY) license (https:// creativecommons.org/licenses/by/ $4.0 /)$.
Instituto de Ciencias de la Vid y el Vino (Universidad de La Rioja, Gobierno de La Rioja, CSIC), Finca La Grajera, Ctra. LO-20 Salida 13, 26071 Logroño, Spain; rocio.escribano@icvv.es (R.E.-V.); lucia.gonzalez@icvv.es (L.G.-A.); pgarijo@larioja.org (P.G.); rosa.lopez@icvv.es (R.L.); psantamaria@larioja.org (P.S.)

* Correspondence: ana-rosa.gutierrez@unirioja.es; Tel.: +34-941894980

\begin{abstract}
The use of non-Saccharomyces yeasts in sequential fermentations with S. cerevisiae has been proposed to improve the organoleptic characteristics involved in the quality of wine. The present study set out to select a non-Saccharomyces inoculum from the D.O.Ca. Rioja for use in winemaking. Strains included in the study belonged to Torulaspora delbrueckii, Lachancea thermotolerans, Metschnikowia pulcherrima, Zygosaccharomyces bailii, Williopsis pratensis, Debaryomyces hansenii, Pichia kluyveri, Sporidiobolus salmonicolor, Candida spp., Cryptococcus spp. and two mixed inocula of Lachancea thermotolerans-Torulaspora delbrueckii in a 30/70 ratio. In the first stage of the process, $\mathrm{SO}_{2}$ resistance and presence of enzymatic activities related to wine aroma and wine color and fining (esterase, esterase-lipase, lipase, leucine arylamidase, valine arylamidase, cystine arylamidase, $\beta$-glucosidase, pectinase, cellulose, xylanase and glucanase) were studied. In the later stages, selection criteria such as fermentative behavior, aroma compound production or influence on phenolic compounds were studied in laboratory scale vinifications. Taking into account the results obtained in the different stages of the process, a mixed inoculum of Lachancea thermotolerans-Torulaspora delbrueckii in a 30/70 ratio was finally selected. This inoculum stood out for its high implantation capacity, the production of compounds of interest such as glycerol and lactic acid and the consequent modulation of wine acidity. Given these characteristics, the selected inoculum is suitable for the production of quality wines.
\end{abstract}

Keywords: selection; non-Saccharomyces; winemaking; Lachancea thermotolerans; Torulaspora delbrueckii

\section{Introduction}

Spontaneous fermentations are complex microbial processes performed by the sequential action of indigenous non-Saccharomyces and Saccharomyces yeasts. The high diversity of species involved in the process gives rise to wines with more complex profiles. However, these fermentations are often associated with extended lag phases and long fermentation times, high residual sugar content and organoleptic defects [1]. These disadvantages, together with the lack of predictability of the process, have led winemakers to seek alternatives to spontaneous fermentations. Currently, the most extended practice in winemaking involves the inoculation of the must with selected $S$. cerevisiae strains in the form of active dry yeasts (ADY). This technique has some advantages, such as the rapid and complete fermentation of the must and great reproducibility of the final product [2]. However, this practice also leads to less complexity and a certain standardization of the wines obtained as a consequence of the reduction of the diversity of the microbial populations involved in the fermentation $[3,4]$.

To avoid homogeneity of the wines inoculated with $S$. cerevisiae commercial strains, the use of selected non-Saccharomyces yeasts in mixed fermentations with $S$. cerevisiae has been proposed. This practice offers some of the advantages of spontaneous fermentations such as higher organoleptic complexity, while allowing greater control of the process, 
avoiding stuck fermentations or possible defects in the wine caused by the indigenous microbiota [4-6].

In the past, non-Saccharomyces yeasts were not considered to be very relevant and were even viewed as spoilage yeasts because of their high production of compounds that could be negative for wine quality, such as acetic acid, ethyl acetate, acetaldehyde or acetoin [7]. However, the recent literature has shown that, through appropriate selection programs, non-Saccharomyces yeast strains can have a positive influence on wine characteristics [8-13].

Among the non-Saccharomyces yeasts that have been studied to improve wine characteristics is Torulaspora delbrueckii, which has been reported to decrease volatile acidity [14] or increase glycerol content [15]. This yeast can modulate the aromatic properties of wines producing high levels of fruity esters, thiols and terpenes [16-18]. Another non-Saccharomyces yeast that has been proposed for use in winemaking is Lachancea thermotolerans. Fermentations with this yeast usually lead to a higher total acidity, which is generally attributed to the production of lactic acid $[19,20]$. The production levels of lactic acid can vary between strains [21,22]. According to the literature, a low production of acetic acid is another feature of this yeast that can contribute to wine quality $[7,23]$.

Technological criteria, such as the $\mathrm{SO}_{2}$ resistance of the yeast strains, are usually taken into account in the selection processes. $\mathrm{SO}_{2}$ is an additive widely used in winemaking, so the resistance of the yeasts to this compound is a relevant characteristic when carrying out the selection process. This is a highly variable trait, varying not only between species but also between yeast strains [24]. In recent years, the qualitative properties of yeasts have been considered of great importance, since they can influence the chemical composition and sensory characteristics of wine [25]. These characteristics include the ability to produce enzymes that can influence the aroma and color of wine or the release of compounds of interest derived from yeast metabolism. The activity of enzymes related to aroma allows the release of aromatic compounds to the wine. As an example, $\beta$-glucosidase enzymes catalyze the release of terpenes from their precursors [26,27]. Other enzymes, such as carbohydrolases, allow the improvement of color extraction in red wines during maceration due to the degradation of structural polysaccharides [28]. Yeast metabolism can lead to the release of compounds that contribute to the quality of the wine such as glycerol, higher alcohols or esters [29-31]. As has been shown in the literature, many of the yeast features that can influence the quality of wine are strain dependent $[4,32,33]$, which highlights the importance of considering metabolic diversity within species, at the strain level.

Many wineries and wine-growing regions have developed programs for the selection of indigenous yeasts, including isolates from the winery's own ecosystem or from its vineyards. This trend is based on the idea that yeasts isolated from these enological environments are better adapted to the ecology and technological characteristics of the musts of the region from which they come [34,35]. The use of autochthonous yeasts can be a useful tool to improve the characteristics of the typical wines of a region due to their adaptation to the environment and an ability to highlight the peculiarities of the product [36-39].

In the current study, the selection process of non-Saccharomyces strains isolated in the Rioja winegrowing region in Spain for use in winemaking is explained. For this study, selection criteria such as $\mathrm{SO}_{2}$ resistance, enzymatic activities or influence on wine aroma and phenolic compounds were taken into account in order to choose the most suitable strain for its use in making red wine.

\section{Materials and Methods}

\subsection{Yeast Isolates}

Non-Saccharomyces yeast isolates included in the selection program were part of the Instituto de Ciencias de la Vid y el Vino (ICVV) collection, composed of more than 500 strains belonging to more than 30 different species. The selection process started with ninety-seven non-Saccharomyces wine yeast strains belonging to ten different genera. 
This initial list included species that had shown good behavior as inocula in previous studies (Lachancea thermotolerans, Metschnikowia pulcherrima, Pichia kluyveri and Torulaspora delbrueckii), and species that had not been previously considered but that had been isolated in different D.O.Ca. Rioja enological ecosystems in previous works [40-42] (Candida spp. and Criptococcus spp. genera, Debaryomyces hansenii, Sporidiobolus salmonicolor, Williopsis pratensis and Zygosaccharomyces bailii). In addition, during the process, two spontaneously developed mixed inocula in two of the studied cultures were detected and included in the study. Furthermore, a commercial strain of Saccharomyces cerevisiae (Uvaferm VRB, Danstar Ferment AB, Fredericia, Denmark) was used as a fermentative reference or as part of the inoculum in sequential inoculations.

\subsection{Genetic Characterization of the Strains at Clonal Level}

In the species in which several isolates were included, they were identified at a clonal level. Thus total of seventy-one strains were characterized by Random Amplification of Polymorphic DNA ((RAPD)-PCR) using the primers M13, M14, Coc, OPA02 and OPA09, following the methodology described by Renault et al. [23] with some modifications [24].

\section{3. $\mathrm{SO}_{2}$ Resistance}

Resistance of the non-Saccharomyces strains to different concentrations of $\mathrm{SO}_{2}(20,40$, 80 and $120 \mathrm{mg} / \mathrm{L}$ ) was studied in tubes with $5 \mathrm{~mL}$ of buffered YPD (1\% yeast extract, $2 \%$ dextrose, $2 \%$ peptone) following the procedure described in González-Arenzana et. al. [43]. The resistance to $\mathrm{SO}_{2}$ was determined by contrasting the growth of the studied strains in the presence of $\mathrm{SO}_{2}$ with the growth of the same strains without $\mathrm{SO}_{2}$. Measures of growth were conducted by reading the absorbance at $600 \mathrm{~nm}$.

\subsection{Enzymatic Characterization}

The presence of enzymatic activities related to wine aroma (esterase, esterase-lipase, lipase, leucine arylamidase, valine arylamidase, cystine arylamidase and $\beta$-glucosidase) and wine color and fining (pectinase, cellulose, xilanase, glucanase, leucine arylamidase, valine arylamidase and cystine arylamidase) was studied in the non-Saccharomyces strains. Enzymatic activities were measured using an API-ZYM test system and different specific media plates as described in Escribano et al. [44]. To carry out the API-ZYM test, yeast cultures were suspended in distilled water until the suspensions reached a turbidity of 5-6 McFarland. $65 \mu \mathrm{L}$ of the culture suspensions were inoculated in each cupule of the API ZYM test strip.

\subsection{Vinifications}

\subsubsection{Pure $100 \mathrm{~mL}$ Vinifications}

In this assay alcoholic fermentations were performed in sterile, $100 \mathrm{~mL}$ Erlenmeyer flasks containing pasteurized $\left(10 \mathrm{~min}\right.$ at $\left.70^{\circ} \mathrm{C}\right)$ Viura grape juice $(206.45 \mathrm{~g} / \mathrm{L}$ initial reducing sugar concentration, $0.93 \mathrm{~g} / \mathrm{L}$ malic acid, 2.36 total acidity expressed as $\mathrm{g} / \mathrm{L}$ of tartaric acid, $150 \mathrm{mg} / \mathrm{L}$ yeast assimilable nitrogen (YAN) and $\mathrm{pH}$ 3.56). The fermentation vessels were sealed with Müller valves filled with $\mathrm{H}_{2} \mathrm{SO}_{4}$. Yeasts were precultured in a YPD liquid medium at $25^{\circ} \mathrm{C}$ for $48 \mathrm{~h}$ before inoculation of the flasks with $10^{6}$ cells $/ \mathrm{mL}$. All the fermentations were carried out in duplicate without $\mathrm{SO}_{2}$ addition at $20^{\circ} \mathrm{C}$ and $70 \mathrm{rpm}$ in an orbital incubator. Fermentation activity was measured daily as weight loss from $\mathrm{CO}_{2}$ release, and fermentations were assessed as stuck when no further weight loss was observed for three consecutive days. Enological parameters and fermentative aromatic compounds were analyzed in final wines and results were compared with those obtained in fermentations performed with a commercial strain of Saccharomyces cerevisiae.

\subsubsection{Sequential $2000 \mathrm{~mL}$ Vinifications}

Vinifications of the following assay were performed in microscale fermenters [45] containing $2000 \mathrm{~mL}$ of red Tempranillo must and $500 \mathrm{~g}$ of pomace obtained after mechanical 
treatment of the grapes, in a conditioned chamber at $25{ }^{\circ} \mathrm{C}$. Assays were carried out in duplicate with unsterilized and unsulfited must (14.5\% probable degree, $2.26 \mathrm{~g} / \mathrm{L}$ malic acid, 4.9 total acidity expressed as $\mathrm{g} / \mathrm{L}$ of tartaric acid, $181 \mathrm{mg} / \mathrm{L}$ YAN and $\mathrm{pH} 3.73)$. Vinifications were conducted with nine strains belonging to six different species [T. delbrueckii (T18 and T19), M. pulcherrima (M28 and M29), L. thermotolerans (L54 and L57), Z. bailii (Z71), W. pratensis (W87) and C. zeylanoides (C342)] and two mixed inocula of L. thermotolerans and $T$. delbrueckii in a 70/30 ratio (LT1 and LT2) in sequential inoculations with $S$. cerevisiae. Non-Saccharomyces yeasts were pre-cultured in YPD liquid medium at $25{ }^{\circ} \mathrm{C}$ for $48 \mathrm{~h}$ before inoculation of flasks with $10^{6}$ cells $/ \mathrm{mL}$. Three days after non-Saccharomyces inoculation, a commercial $S$. cerevisiae strain was inoculated at a density of $1 \times 10^{6}$ cells $/ \mathrm{mL}$. Fermentation activity was measured daily as Brix decrease. Wines were pressed 14 days after inoculation, sulfited at $30 \mathrm{mg} / \mathrm{L}$ and left to settle for a week. Enological parameters and fermentative aromatic compounds were analyzed in final wines and results were compared with those obtained in fermentations performed only with a commercial strain of Saccharomyces cerevisiae.

\subsection{Microbial Analysis and Implantation Controls of the Seeded Yeasts}

Samples for microbial studies were taken at different times throughout the fermentations. In pure fermentations samples for implantation controls were taken under aseptic conditions on day 7 (tumultuous fermentation) and at the end of fermentation (day 14). In sequential fermentations samples were taken daily under aseptic conditions. Serial dilutions were carried out and the samples were seeded onto plates containing a chloramphenicol glucose agar medium $(0.5 \%$ yeast extract, $20 \%$ glucose, $0.05 \%$ chloramphenicol, $17 \%$ agar). The plates were incubated at $25^{\circ} \mathrm{C}$ for $48 \mathrm{~h}$. Ten colonies from each sample were randomly selected from plates containing between 30 and 300 colony forming units per milliliter (CFU/mL).

The extraction of DNA for the identification of the isolates was conducted from the fresh yeast culture, using the method suggested by López et al. [46]. Domains D1/D2 of the 26S rDNA gene were amplified by PCR using primers and conditions described by Kurtzman and Fell [47]. The PCR products were purified and then sequenced at the facilities of Macrogen Inc. (Amsterdam, The Netherlands) in order to determine which species of yeast each isolate belonged to (according to data retrieved from GenBank: www.ncbi.nlm.nih.gov/blast/blast.org, accessed on 10 February 2017). The identification was considered correct when gene sequences showed identities of at least $98 \%$.

\subsection{Analysis of Enological Parameters in Wines}

Wines were characterized by measuring the alcohol strength, $\mathrm{pH}$, total acidity and volatile acidity according to official European Economic Community EEC methods [48]. Moreover, the malic and lactic acids, glycerol, acetaldehyde and residual sugars were determined by an enzymatic method carried out in a MIURA One enological analyzer (TDI, Barcelona, Spain). Total anthocyanins were measured by decoloring using $\mathrm{SO}_{2}$ [49].

\subsection{Analysis of Aromatic Compounds}

The analysis of fermentative aromatic compounds in wine was performed by gas chromatography using the method described by Ortega et al. [50] with minor modifications [51]. Extracted samples were injected onto a 6890 series II gas chromatograph (Hewlett-Packard, Palo Alto, CA, USA) equipped with an automatic injector and a Hewlett-Packard FID detector. Separation was carried out with a DB-Wax capillary column $(60 \mathrm{~m} \times 0.32 \mathrm{~mm}$ I.D. $\times$ $0.5 \mu \mathrm{m}$ film thickness; J\&W Scientific, Folsom, CA, USA). Identification of compounds was carried out by comparison of their retention times with those of pure reference standards using a Hewlett-Packard GCD Series II Gas Chromatograph Electron Ionization Detector. 


\subsection{Analysis of Stilbenes}

In stilbene analysis, a previous purification step was conducted by solid phase extraction (SPE) [52] with PCX SPE cartridges (500 mg, 6 mL; Bond Elut Plexa, Agilent, Palo Alto, CA, USA) placed in a Gilson GX-271 Spec (Gilson Inc., Middleton, WI, USA). The fraction obtained from the SPE step was analyzed by HPLC-DAD using an Agilent 1260 Infinity system following the methodology adapted from Portu et al. [53]. Wine samples were injected into a LiCrospher R $100 \mathrm{RP}-18$ reversed-phase column (Agilent) with precolumn LiCrospher R 100 RP-18 (Agilent), both thermostated at $40{ }^{\circ} \mathrm{C}$. Flow rate was at $0.500 \mathrm{~mL} / \mathrm{min}$ and injection volume was $20 \mathrm{~mL}$. Solvent A was water/acetonitrile/formic acid (100:10:0.1, $v / v / v)$ and solvent $B$ was acetonitrile. The linear solvent gradient was: $0 \mathrm{~min}, 0 \% \mathrm{~B} ; 20.8 \mathrm{~min}, 16 \% \mathrm{~B} ; 32.8 \mathrm{~min}, 16 \% \mathrm{~B} ; 49.4 \mathrm{~min}, 42 \% \mathrm{~B} ; 60 \mathrm{~min}, 0 \% \mathrm{~B}$.

\subsection{Statistical Analysis}

Analysis of variance (ANOVA) was carried out for all the parameters analyzed for the different assays with the IBM ${ }^{\circledR}$ SPSS $^{\circledR}$ Statistics version 23 (company, city, state abbrev if USA, country). Significant differences were established by using the Tukey post hoc test $(p \leq 0.05)$.

\section{Results}

\subsection{Clonal Characterization of Non-Saccharomyces Strains}

In order to evaluate clonal diversity among the most representative non-Saccharomyces yeasts included in the study, genetic characterization was carried out in 71 isolates of five different species (T. delbrueckii, M. pulcherrima, L. thermotolerans, Z. bailii and W. pratensis). RAPD analysis allowed the differentiation of 17 clones among the 21 isolates of T. delbrueckii, 13 clones among the 16 isolates of M. pulcherrima, 15 clones among the 16 isolates of L. thermotolerans and 7 clones among the seven isolates of Z. bailii and the 11 isolates of W. pratensis. Results obtained showed high clonal diversity among the studied species [43].

\section{2. $\mathrm{SO}_{2}$ Resistance}

Resistance to $\mathrm{SO}_{2}$ was evaluated after 24 and $48 \mathrm{~h}$ in the same isolates in which clonal diversity was assessed. The percentage of isolates in each species able to grow at the same level as the control in different concentrations of $\mathrm{SO}_{2}$ at $24 \mathrm{~h}$ is shown in Figure 1. Strains of T. delbrueckii and Z. bailii showed the best adaptation at $24 \mathrm{~h}$. At that timepoint, $52.4 \%$ of $T$. delbrueckii isolates were able to grow at a similar level as the control in media containing $40 \mathrm{mg} / \mathrm{L}$ of $\mathrm{SO}_{2}$, and $19.0 \%$ were able to grow with a concentration of $80 \mathrm{mg} / \mathrm{L}$. In contrast, isolates of M. pulcherrima showed less tolerance to this compound. $56.3 \%$ of the isolates were not able to grow in the medium with a dose of $20 \mathrm{mg} / \mathrm{L}$ of $\mathrm{SO}_{2}$ and the remaining isolates only tolerated that concentration. Isolates of $L$. thermotolerans also tolerated low levels of $\mathrm{SO}_{2}$, but the proportion tolerating at least $20 \mathrm{mg} / \mathrm{L}$ was higher than in M. pulcherrima, with $81.3 \%$ of the isolates. Results showed better adaptation of the strains at $48 \mathrm{~h}$, but the ability to develop rapidly in presence of $\mathrm{SO}_{2}$ during vinification is an advantage for the yeast to establish in the medium. For that reason, growth at $24 \mathrm{~h}$ was considered as the selection criterion for $\mathrm{SO}_{2}$ tolerance.

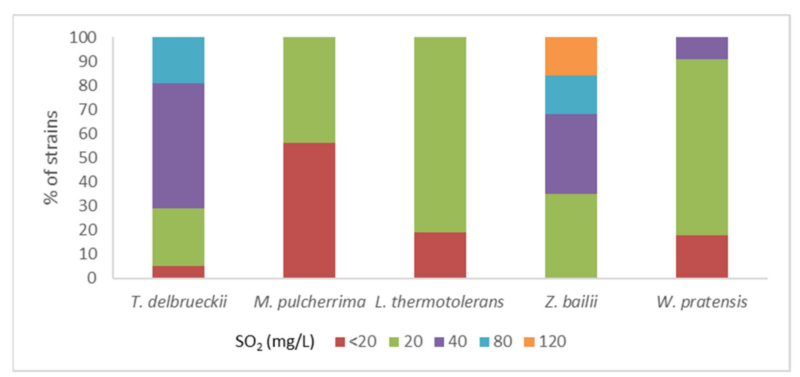

Figure 1. Distribution of strains within each species according to the maximum level of $\mathrm{SO}_{2}$ which allowed a strain growth similar to control at $24 \mathrm{~h} \mathrm{[54].}$ 


\subsection{Screening of Enzymatic Activities}

Enzymatic activities were studied in non-Saccharomyces strains belonging to ten different genera and species (Candida spp., Criptococcus spp., Debaryomyces hansenii, Lachancea thermotolerans, Metschnikowia pulcherrima, Pichia kluyveri, Sporidiobolus salmonicolor, Torulaspora delbrueckii, Williopsis pratensis and Zygosaccharomyces bailii). After determination of the enzymatic activities present in the strains, they were classified into different profiles related with wine aroma and color and fining in order to facilitate the selection of the most suitable strains depending on the type of wine or the desired characteristics to be modulated. Profiles related to aroma were named with an " $\mathrm{A}$ " and profiles related to color and fining were named with a " $\mathrm{C}$ " after the initials of the species or genera.

Enzymatic profiles related to aroma (Table 1 ) within each species were mainly differentiated by esterase, esterase-lipase and $\beta$-glucosidase activities. The $\beta$-glucosidase breaks down the terpenes combined with the sugars to release them, thus enhancing the varietal aroma of the wine. Lipases contribute to an increase in the concentrations of free fatty acids and esterases catalyze the synthesis of esters that contribute to the secondary aroma of wines. Esterase and esterase-lipase were the most widespread activities among the studied strains. All the strains of Cryptococcus spp. genera and W. pratensis, S. salmonicolor, P. kluyveri and M. pulcherrima species showed esterase activity. Similarly, esterase-lipase was detected in all the strains of Candida spp., Cryptococcus spp., W. pratensis, S. salmonicolor, P. kluyveri, M. pulcherrima and L. thermotolerans. On the other hand, lipase activity was scarcely detected and only was found in some strains of S. salmonicolor and L. thermotolerans.

Table 2 shows enzymatic profiles found in each species/genera based on the enzymes involved in color and clarity of wine. The degradation of structural polysaccharides by enzymes such as pectinase, cellulose, xylanase, and glucanase, can result in greater extraction of substances that enhance color and improve clarification and filterability during winemaking. Regarding these enzymes, the activity most frequently detected among the strains was pectinase. Nevertheless, in many species there were profiles that did not show any of the carbohydrolase activities. The proteolytic enzymes (leucine arylamidase, valine arylamidase, cystine arylamidase) increase the amino acid content, improving the production of aromatic compounds in the wine $[55,56]$ and they are also involved in reducing protein instability in wines [57]. Within this group of aminopeptidases, $W$. pratensis showed the three activities studied in nine out of ten strains. As happened with carbohydrolases, there were also some strains that did not show any of the aminopeptidase activities. Profile LC6 of $L$. thermotolerans stood out for being the only one in which all the activities of these groups of enzymes were detected (the four carbohydrolases and the three aminopeptidases).

Table 1. Specific enzymatic profiles related to wine aroma.

\begin{tabular}{|c|c|c|c|c|c|c|c|c|}
\hline \multirow{2}{*}{ Species/Profiles } & \multirow{2}{*}{$\mathbf{N}$} & \multicolumn{7}{|c|}{ Enzymatic Activities } \\
\hline & & Esterase & Esterase-Lipase & Lipase & LeucineA & ValineA & CystineA & $\beta$-Glucosidase \\
\hline \multicolumn{9}{|l|}{ Candida spp. (C) } \\
\hline CA 1 & 5 & + & + & - & + & + & - & - \\
\hline CA 2 & 3 & + & + & - & + & - & - & - \\
\hline CA 3 & 1 & - & + & - & + & + & - & - \\
\hline CA 4 & 1 & - & + & - & + & + & - & + \\
\hline CA 5 & 2 & + & + & - & + & + & - & + \\
\hline \multicolumn{9}{|c|}{ Cryptococcus spp. (CC) } \\
\hline CCA 1 & 2 & + & + & - & + & - & - & + \\
\hline CCA 2 & 1 & + & + & - & + & - & - & + \\
\hline CCA 3 & 2 & + & + & - & + & - & - & - \\
\hline \multicolumn{9}{|c|}{ Debaryomyces hansenii (D) } \\
\hline DA 1 & 1 & - & - & - & - & - & - & - \\
\hline DA 2 & 1 & + & + & - & - & - & - & - \\
\hline DA 3 & 1 & + & + & - & - & - & - & - \\
\hline
\end{tabular}


Table 1. Cont.

\begin{tabular}{|c|c|c|c|c|c|c|c|c|}
\hline \multirow{2}{*}{ Species/Profiles } & \multirow{2}{*}{$\mathbf{N}$} & \multicolumn{7}{|c|}{ Enzymatic Activities } \\
\hline & & Esterase & Esterase-Lipase & Lipase & LeucineA & ValineA & CystineA & $\beta$-Glucosidase \\
\hline \multicolumn{9}{|c|}{ Lachancea thermotolerans (L) } \\
\hline LA 1 & 11 & + & + & - & + & + & - & - \\
\hline LA 2 & 1 & + & + & - & + & - & - & - \\
\hline LA 3 & 1 & - & + & - & + & + & - & - \\
\hline LA 4 & 1 & + & + & + & + & + & - & - \\
\hline LA 5 & 1 & + & + & + & + & + & - & + \\
\hline LA 6 & 1 & + & + & - & + & + & + & - \\
\hline \multicolumn{9}{|c|}{ Metschnikowia pulcherrima (M) } \\
\hline MA 1 & 5 & + & + & - & + & - & - & - \\
\hline MA 2 & 2 & + & + & - & + & - & - & + \\
\hline MA 3 & 1 & + & + & - & - & + & - & - \\
\hline MA 4 & 5 & + & + & - & + & + & - & + \\
\hline MA 5 & 2 & + & + & - & + & - & - & + \\
\hline MA 6 & 1 & + & + & - & + & + & - & + \\
\hline \multicolumn{9}{|l|}{ Pichia kluyveri (PK) } \\
\hline PKA 1 & 4 & + & + & - & + & - & - & - \\
\hline \multicolumn{9}{|c|}{ Sporodiobulus salmonicolor (SP) } \\
\hline SPA 1 & 4 & + & + & - & + & + & - & - \\
\hline SPA 2 & 2 & + & + & + & + & + & - & - \\
\hline \multicolumn{9}{|c|}{ Torulaspora delbrueckii (T) } \\
\hline TA 1 & 1 & + & + & - & - & - & - & - \\
\hline TA 2 & 5 & - & - & - & - & - & - & - \\
\hline TA 3 & 8 & + & + & - & + & - & - & - \\
\hline TA 4 & 3 & - & - & - & + & - & - & - \\
\hline TA 5 & 1 & + & + & - & + & - & + & - \\
\hline \multicolumn{9}{|c|}{ Williopsis pratensis $(\mathrm{W})$} \\
\hline WA 1 & 9 & + & + & - & + & + & + & - \\
\hline WA 2 & 1 & + & + & - & + & + & - & - \\
\hline \multicolumn{9}{|c|}{ Zygosaccharomyces bailii (Z) } \\
\hline ZA 1 & 1 & + & + & - & + & - & - & - \\
\hline ZA 2 & 1 & + & - & - & + & - & - & - \\
\hline ZA 3 & 1 & + & + & - & + & - & - & + \\
\hline ZA 4 & 2 & - & + & - & + & - & - & - \\
\hline ZA 5 & 2 & + & + & - & + & - & - & - \\
\hline
\end{tabular}

Presence (+) or absence (-) of each activity; N: number of strains in each enzymatic profile.

Table 2. Specific enzymatic profiles related to color and fining.

\begin{tabular}{|c|c|c|c|c|c|c|c|c|}
\hline \multirow{2}{*}{ Species/Profiles } & \multirow{2}{*}{$\mathbf{N}$} & \multicolumn{7}{|c|}{ Enzymatic Activities } \\
\hline & & Pectinase & Cellulase & Xilanase & Glucanase & LeucineA & ValineA & CystineA \\
\hline \multicolumn{9}{|l|}{ Candida spp. (C) } \\
\hline CC 1 & 3 & + & - & - & - & + & + & - \\
\hline $\mathrm{CC} 2$ & 3 & + & - & - & - & + & - & - \\
\hline $\mathrm{CC} 3$ & 6 & - & - & - & - & + & + & - \\
\hline \multicolumn{9}{|c|}{ Cryptococcus spp. (CC) } \\
\hline CCC 1 & 2 & - & + & - & + & + & - & - \\
\hline CCC 2 & 1 & + & + & - & + & + & - & - \\
\hline $\mathrm{CCC} 3$ & 2 & + & - & - & - & + & - & - \\
\hline \multicolumn{9}{|c|}{ Debaryomyces hansenii (D) } \\
\hline DC 1 & 1 & + & - & - & + & - & - & - \\
\hline DC 2 & 1 & + & + & - & + & - & - & - \\
\hline DC 3 & 1 & + & - & - & - & - & - & - \\
\hline
\end{tabular}


Table 2. Cont.

\begin{tabular}{|c|c|c|c|c|c|c|c|c|}
\hline \multirow{2}{*}{ Species/Profiles } & \multirow{2}{*}{$\mathbf{N}$} & \multicolumn{7}{|c|}{ Enzymatic Activities } \\
\hline & & Pectinase & Cellulase & Xilanase & Glucanase & LeucineA & ValineA & CystineA \\
\hline \multicolumn{9}{|c|}{ Lachancea thermotolerans (L) } \\
\hline LC 1 & 9 & - & + & + & + & + & + & - \\
\hline LC 2 & 2 & - & + & - & + & + & + & - \\
\hline LC 3 & 1 & - & - & - & + & + & + & - \\
\hline LC 4 & 2 & - & - & - & - & + & + & - \\
\hline LC 5 & 1 & + & - & - & - & + & + & - \\
\hline LC 6 & 1 & + & + & + & + & + & + & + \\
\hline \multicolumn{9}{|c|}{ Metschnikowia pulcherrima (M) } \\
\hline MC 1 & 5 & + & - & - & - & + & - & - \\
\hline MC 2 & 2 & + & + & - & - & - & - & - \\
\hline $\mathrm{MC} 3$ & 2 & + & - & - & - & + & + & - \\
\hline MC 4 & 1 & + & + & - & - & + & - & - \\
\hline MC 5 & 2 & - & + & - & - & + & + & - \\
\hline MC 6 & 1 & - & - & - & + & + & + & - \\
\hline \multicolumn{9}{|c|}{ Pichia kluyveri (PK) } \\
\hline PKC 1 & 4 & + & - & - & - & + & - & - \\
\hline \multicolumn{9}{|c|}{$\begin{array}{l}\text { Sporodiobulus salmonicolor } \\
\text { (SP) }\end{array}$} \\
\hline SPC 1 & 4 & + & - & - & - & + & + & - \\
\hline SPC 2 & 2 & - & - & - & - & + & + & - \\
\hline \multicolumn{9}{|c|}{ Torulaspora delbrueckii (T) } \\
\hline TC 1 & 5 & + & - & - & - & - & - & - \\
\hline TC 2 & 1 & - & - & - & - & - & - & - \\
\hline TC 3 & 2 & - & - & - & - & + & - & - \\
\hline TC 4 & 2 & + & + & + & - & + & - & - \\
\hline TC 5 & 7 & + & - & - & - & + & - & - \\
\hline TC 6 & 1 & + & - & - & - & + & - & + \\
\hline \multicolumn{9}{|c|}{ Williopsis pratensis $(\mathrm{W})$} \\
\hline WC 1 & 9 & - & - & - & - & + & + & + \\
\hline WC 2 & 1 & - & - & - & - & + & - & - \\
\hline \multicolumn{9}{|c|}{ Zygosaccharomyces bailii (Z) } \\
\hline $\mathrm{ZC} 1$ & 2 & + & + & - & - & + & - & - \\
\hline $\mathrm{ZC} 2$ & 3 & + & - & - & - & + & - & - \\
\hline ZC 3 & 2 & - & - & - & - & + & - & - \\
\hline
\end{tabular}

Presence $(+)$ or absence (-) of each activity; N: number of strains in each enzymatic profile.

3.4. Fermentative Behavior and Aromatic Compound Production of Non-Saccharomyces Strains in Pure 100 mL Vinifications

Taking into account results obtained in the previous steps of the selection process, twenty-four strains belonging to eight different species (three strains of Candida zeylanoides, one strain of Cryptococcus uzbekistanensis, Debaryomyces hansenii and Zygosaccharomyces bailii, five strains of Metschnikowia pulcherrima and Williopsis pratensis and four strains of Lachancea thermotolerans, and Torulaspora delbrueckii) were selected to continue the study. Since Pichia kluyveri and Sporodiobolus salmonicolor strains were not able to grow in liquid medium, they were eliminated from the study.

The establishment of the inoculated yeasts was total in most cases, with the exception of musts inoculated with $W$. pratensis, two of the strains of $C$. zeylanoides and the strain of $C r$. uzbekistanensis. As these yeasts were not able to develop in the must, they were eliminated from the selection process and data corresponding to them were not included in the results.

Analysis of fermentative features showed that $S$. cerevisiae was the only yeast capable of consuming all the sugar (Table 3). C. zeylanoides showed the highest levels of acetic acid and acetaldehyde among the yeasts studied, ahead of Z. bailii, which was the next species 
with the highest values. L. thermotolerans and Z. bailii showed the ability to increase the acidity of the wine due to the production of lactic acid and to the production of malic acid, respectively. The highest levels of glycerol were also found in Z. bailii, followed by those detected in L. thermotolerans and M. pulcherrima.

Table 3. Enological traits of wines fermented by different non-Saccharomyces yeast species and statistical analysis [58].

\begin{tabular}{|c|c|c|c|c|c|c|c|}
\hline \multirow[b]{2}{*}{ Parameters } & \multicolumn{7}{|c|}{ Yeast Species } \\
\hline & D. hansenii & C. zeylanoides & M. pulcherrima & $\begin{array}{c}T . \\
\text { delbrueckii }\end{array}$ & L. thermotolerans & $\underset{\text { bailii }}{Z}$ & S. cerevisiae \\
\hline Residual sugars (g/L) & $201.0 \mathrm{e}$ & $151.1 \mathrm{~d}$ & $111.2 \mathrm{~cd}$ & $47.2 \mathrm{~b}$ & $75.6 \mathrm{bc}$ & $96.6 \mathrm{c}$ & $0.08 \mathrm{a}$ \\
\hline$\%$ sugar $(72 \mathrm{~h})$ & $00.0 \mathrm{a}$ & $10.5 \mathrm{ab}$ & $15.5 \mathrm{~b}$ & $24.5 \mathrm{bc}$ & $23.0 \mathrm{~b}$ & $12.0 \mathrm{ab}$ & $39.5 c$ \\
\hline Ethanol $(\% v / v)$ & $0.11 \mathrm{a}$ & $2.99 \mathrm{~b}$ & $5.31 \mathrm{c}$ & $9.83 \mathrm{e}$ & $8.22 \mathrm{de}$ & $6.33 \mathrm{~cd}$ & $12.60 \mathrm{f}$ \\
\hline Glycerol (g/L) & $0.55 \mathrm{a}$ & $3.10 \mathrm{~b}$ & 4.80 de & $4.05 \mathrm{c}$ & $4.65 \mathrm{~d}$ & $5.60 \mathrm{f}$ & 5.20 ef \\
\hline $\mathrm{pH}$ & $3.54 \mathrm{~b}$ & $3.45 \mathrm{~b}$ & $3.46 \mathrm{~b}$ & $3.47 \mathrm{~b}$ & $3.26 \mathrm{a}$ & $3.25 \mathrm{a}$ & $3.43 \mathrm{~b}$ \\
\hline Total acidity (g/L) & $2.30 \mathrm{a}$ & $3.30 \mathrm{~b}$ & $3.50 \mathrm{~b}$ & $3.25 \mathrm{~b}$ & $5.70 \mathrm{~d}$ & $4.40 \mathrm{c}$ & $3.55 \mathrm{~b}$ \\
\hline Volatile acidity (g/L) & $0.12 \mathrm{ab}$ & $0.41 \mathrm{e}$ & $0.05 \mathrm{a}$ & $0.22 \mathrm{c}$ & $0.26 \mathrm{~cd}$ & $0.34 \mathrm{de}$ & $0.20 \mathrm{bc}$ \\
\hline Acetaldehyde (mg/L) & $0.00 \mathrm{a}$ & $45.0 \mathrm{~b}$ & $11.5 \mathrm{a}$ & $7.50 \mathrm{a}$ & $17.5 \mathrm{a}$ & $21.5 \mathrm{ab}$ & $19.5 \mathrm{a}$ \\
\hline Malic acid (g/L) & $0.90 \mathrm{bc}$ & $0.95 \mathrm{c}$ & $0.90 \mathrm{bc}$ & $0.71 \mathrm{a}$ & $0.74 \mathrm{ab}$ & $1.26 \mathrm{~d}$ & $0.69 \mathrm{a}$ \\
\hline Lactic acid (g/L) & $0.13 \mathrm{a}$ & $0.13 \mathrm{a}$ & $0.12 \mathrm{a}$ & $0.11 \mathrm{a}$ & $3.81 \mathrm{~b}$ & $0.09 \mathrm{a}$ & $0.09 \mathrm{a}$ \\
\hline
\end{tabular}

Different letters mean significant differences between species $(p \leq 0.05)$.

The aromatic composition of wines was determined by analyzing a total of 30 aromatic compounds. Table 4 shows concentrations of the main groups of aromatic compounds, ethyl acetate, acetoin and diacetyl. Results showed a higher concentration of higher alcohols in M. pulcherrima and S. cerevisiae. D. hansenii and C. zeylanoides, both with low fermentation power, produced the lowest concentrations of higher alcohols. The presence of these compounds in concentrations below $350 \mathrm{mg} / \mathrm{L}$ contributes to the aromatic complexity of the wine, while levels above $400 \mathrm{mg} / \mathrm{L}$ can be negative, since they produce pungent odors [59]. M. pulcherrima showed the highest values of 2-phenylethanol and also reached the highest levels of 2-phenyethyl acetate (data not shown). This rose-scented compound contributes positively to the bouquet of wine [60]. Higher levels of ethyl acetate were observed in M. pulcherrima than in the rest of the species. M. pulcherrima also showed elevated levels of diacetyl and acetoin. Together with M. pulcherrima, C. zeylanoides was the only yeast that exceeded the limit value of $150 \mathrm{mg} / \mathrm{L}$ for acetoin, above which it can provide unpleasant buttery aromas [61]. Small differences were also detected in other aromatic compounds among the different species, but especially between $S$. cerevisiae and non-Saccharomyces yeasts (sum of acetates, esters and acids) [58].

Table 4. Concentrations of aromatic compounds $(\mathrm{mg} / \mathrm{L})$ in wines made with different non-Saccharomyces yeast species and statistical analysis [58].

\begin{tabular}{|c|c|c|c|c|c|c|c|}
\hline \multirow{2}{*}{ Parameters } & \multicolumn{7}{|c|}{ Yeast Species } \\
\hline & D. hansenii & C. zeylanoides & M. pulcherrima & T. delbrueckii & L. thermotolerans & Z. bailii & S. cerevisiae \\
\hline$\sum$ higher alcohols & $11.2 \mathrm{a}$ & $62.0 \mathrm{ab}$ & $272 \mathrm{e}$ & $178 \mathrm{~cd}$ & 215 cde & $130 \mathrm{bc}$ & $264 \mathrm{de}$ \\
\hline$\sum$ acetates & $0.00 \mathrm{a}$ & $0.05 \mathrm{a}$ & $0.21 \mathrm{a}$ & $0.09 \mathrm{a}$ & $0.20 \mathrm{a}$ & $0.19 \mathrm{a}$ & $1.10 \mathrm{~b}$ \\
\hline$\sum$ esters & $0.01 \mathrm{a}$ & $0.03 \mathrm{a}$ & $0.30 \mathrm{bc}$ & $0.46 \mathrm{~d}$ & $0.36 \mathrm{~cd}$ & $0.20 \mathrm{~b}$ & $0.71 \mathrm{e}$ \\
\hline$\sum$ Acids & $0.79 \mathrm{ab}$ & $0.96 \mathrm{ab}$ & $0.67 \mathrm{a}$ & $3.57 \mathrm{c}$ & $2.20 \mathrm{~b}$ & $1.10 \mathrm{ab}$ & $9.10 \mathrm{~d}$ \\
\hline Ethyl acetate & $0.22 \mathrm{a}$ & $2.30 \mathrm{a}$ & $269 c$ & $33.4 \mathrm{ab}$ & $51.7 \mathrm{~b}$ & $31.1 \mathrm{ab}$ & $22.7 \mathrm{ab}$ \\
\hline Acetoin & $69.7 \mathrm{ab}$ & $272 \mathrm{~d}$ & $184 \mathrm{c}$ & $4.50 \mathrm{a}$ & $99.3 \mathrm{~b}$ & $23.4 \mathrm{ab}$ & $5.20 \mathrm{a}$ \\
\hline Dyacetil & $0.04 \mathrm{a}$ & $0.38 \mathrm{a}$ & $2.10 \mathrm{~b}$ & $0.30 \mathrm{a}$ & $0.40 \mathrm{a}$ & $0.10 \mathrm{a}$ & $0.05 \mathrm{a}$ \\
\hline
\end{tabular}

Different letters mean significant differences between species $(p \leq 0.05)$.

In addition to a comparison between species, differences in analytical parameters of strains within the same species were studied (data not shown) [58]. Species in which different strains were included were T. delbrueckii (four strains), L. thermotolerans (four strains) and M. pulcherrima (five strains). Less significant differences were found among 
strains within these species than those found among the different species. In T. delbrueckii significant differences between genotypes were detected only in four parameters: malic acid consumed, volatile acidity and concentration of 1-butanol and isovaleric acid. The four clones of $L$. thermotolerans were differentiated mainly by the acidity parameters (see Table S4 in Supplementary Materials). Lactic acid production, characteristic of L. thermotolerans, varied widely among the clones studied. One of the parameters that showed significant differences between clones in the three species studied was volatile acidity. In addition, in M. pulcherrima and L. thermotolerans, significant differences were observed in ethyl acetate and acetoin, which can also give rise to aromatic defects. These results underline the importance of strain selection for their use in winemaking.

3.5. Influence of Sequential Inoculations with Non-Saccharomyces/S. cerevisiae on Wine Aroma and Composition of Anthocyanins and Stilbenes in $2000 \mathrm{~mL}$ Vinifications

As it was expected, the previous assay showed that none of the non-Saccharomyces strains included in the study was able to complete fermentation. For that reason, in this stage of the selection process sequential fermentations with a commercial strain of S. cerevisiae were performed in order to ensure complete fermentation of the must.

After analyzing results obtained in the previous steps of the study, nine strains belonging to six different species [T. delbrueckii (T18 and T19), M. pulcherrima (M28 and M29), L. thermotolerans (L54 and L57), Z. bailii (Z71), W. pratensis (W87) and C. zeylanoides (C342)] and two mixed inocula of $L$. thermotolerans and T. delbrueckii in a 70/30 ratio (LT1 and LT2) were selected to evaluate their influence on wine quality in sequential inoculations with S. cerevisiae. Results were compared with those obtained in wines fermented only with S. cerevisiae. During the development of the study, it was observed that two of the L. thermotolerans strains (L54 and L57) developed in the must together with T. delbrueckii, both in a 30/70 ratio. Due to the interest that this combination of strains could have in winemaking, it was decided to include the mixed inocula in the following assays.

Control of the presence of the inoculated yeasts showed that on day four $(24 \mathrm{~h}$ after inoculation of S. cerevisiae), Z. bailii, W. pratensis, C. zeylanoides and one strain of M. pulcherrima were not present in the medium. The rest of the yeasts (the other $M$. pulcherrima strain and the two L. thermotolerans strains) disappeared in the next two days and only the two $T$. delbrueckii clones remained in the medium until day six. Regarding the L. thermotolerans/T. delbrueckii mixed cultures, it was observed that they maintained percentages similar to initial proportions (30/70) until S. cerevisiae was inoculated (Figure 2). After that, population of the mixed inocula decreased until they disappeared in seven days.

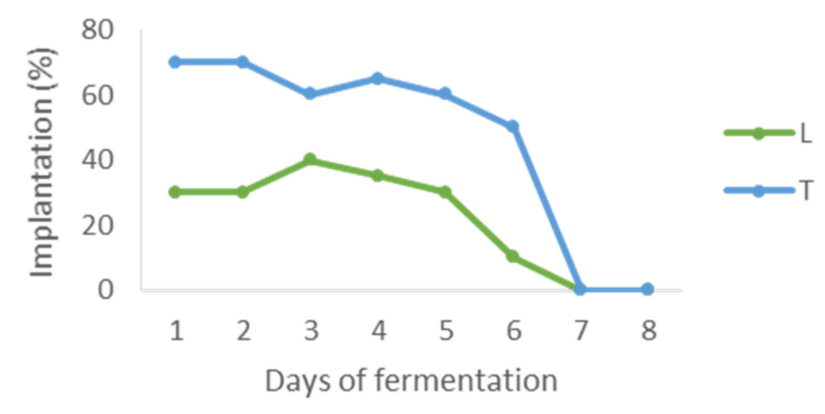

Figure 2. Presence of the yeasts of the mixed inoculum LT1 during the fermentation (L: Lachancea thermotolerans, T: Torulaspora delbrueckii).

Regarding analytical characteristics of wines after alcoholic fermentation (see Table S5 in Supplementary Materials), in general, wines corresponding to sequential inoculations with non-Saccharomyces yeasts showed an increase in glycerol and acetaldehyde levels, lower volatile acidity and a higher consumption of malic acid compared to wines fermented with S. cerevisiae alone. 
Table 5 shows aromatic compounds that presented significant differences in wines sequentially fermented with different non-Saccharomyces yeasts and S. cerevisiae. The wines sequentially inoculated with $T$. delbrueckii and L. thermotolerans exhibited a significant increase in the concentration of higher alcohols compared to those fermented only with S. cerevisiae. Levels of isobutanol were higher in wines made with $L$. thermotolerans and strains T18 and M28 of T. delbrueckii and M. pulcherrima than in wines fermented only with S. cerevisiae. Wines inoculated with T. delbrueckii showed higher concentrations of 2-phenylethanol, 1-butanol and methionol ((3-methylthio)propionol) than the wines fermented only with S. cerevisiae. In M. pulcherrima samples, high levels of methionol were also found and T. delbrueckii and L. thermotolerans showed concentrations of 1-propanol higher than those detected in S. cerevisiae. No significant differences were found in ester and acid content in the final wines (data not shown). Regarding acetates, wines made with $W$. pratensis showed the highest levels, but the differences were only significant with respect to strain L54 of L. thermotolerans. The highest levels of diacetyl were detected in T. delbrueckii, except for one of the strains of $L$. thermotolerans, which showed the highest value of this compound. Diacetyl levels remained below this threshold value in all samples. In wines inoculated with $L$. thermotolerans the levels of acetoin and ethyl lactate were the highest. Acetoin is a compound with a relatively high detection value $(150 \mathrm{mg} / \mathrm{L})$ [61] that was not exceeded in any of the samples.

With regard to total anthocyanins concentration, the wines inoculated only with S. cerevisiae reached a total anthocyanin content of $221 \mathrm{mg} / \mathrm{L}$. The wines obtained by sequential inoculation with $W$. pratensis, L. thermotolerans, and the mixed inocula LT did not show significant differences in anthocyanin content with respect to $S$. cerevisiae. On the other hand, in wines inoculated with M. pulcherrima, T. delbrueckii, Z. bailii and C. zeylanoides, a significant increase in anthocyanin content was observed compared to wines fermented with S. cerevisiae alone (Figure 3).

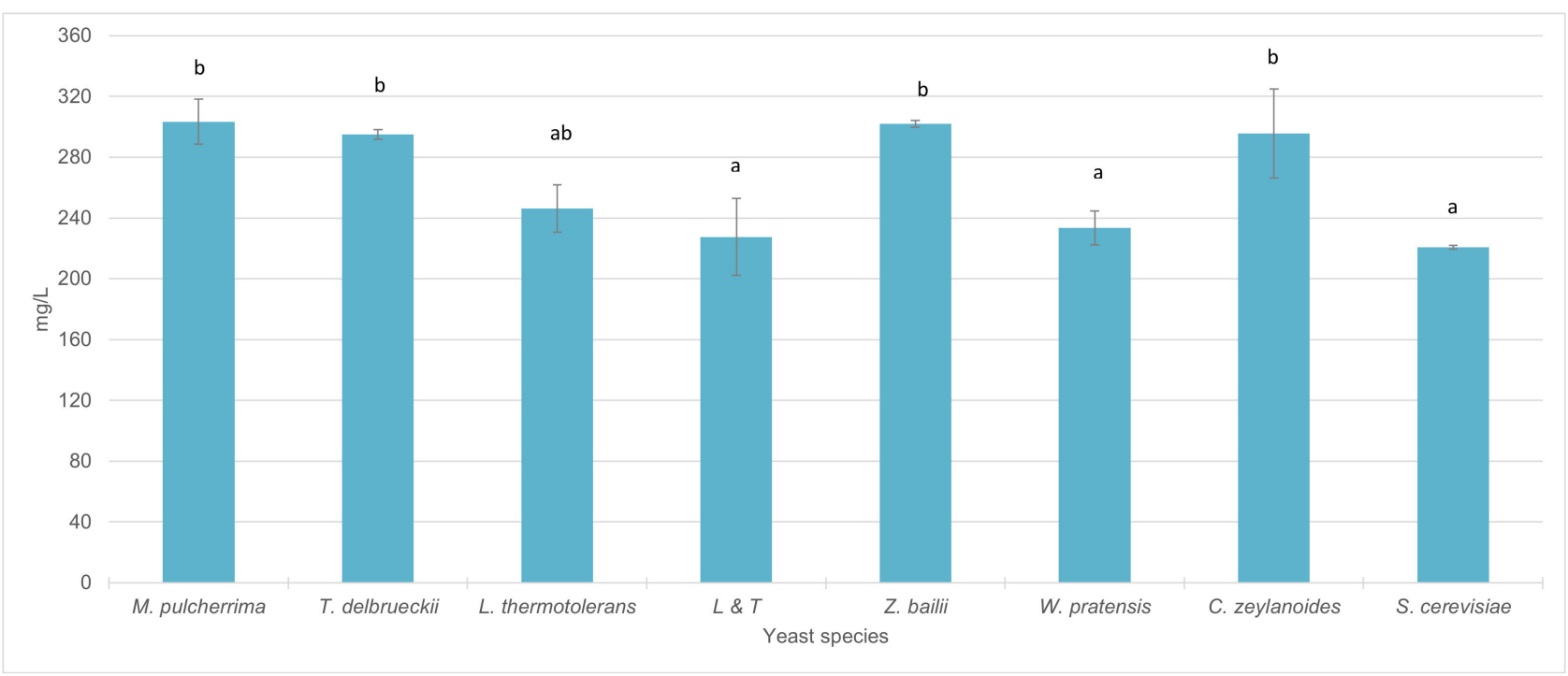

Figure 3. Total anthocyanin content $(\mathrm{mg} / \mathrm{L})$ in wines sequentially fermented with different yeast species. (Average of the different strains in each species included in the study). Different letters mean significant differences between the samples $(p \leq 0.05)$.

Figure 4 presents the total stilbene content in wines inoculated with the different yeasts included in this part of the study. Vinifications with $S$. cerevisiae exhibited the lowest level of total stilbenes. In wines inoculated with C. zeylanoides, T. delbrueckii and Z. bailii, the increase in total content of stilbenes was significant with respect to vinifications with S. cerevisiae. In the rest of the genera, significant differences were not observed respect to S. cerevisiae. 


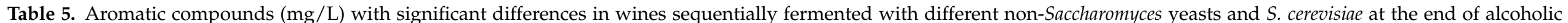
fermentation [62].

\begin{tabular}{|c|c|c|c|c|c|c|c|c|c|c|c|c|}
\hline \multirow{2}{*}{ Parameters } & \multicolumn{12}{|c|}{ Yeast Strains } \\
\hline & T18 & T19 & M28 & M29 & L54 & L57 & LT1 & LT2 & Z71 & W87 & C342 & SC \\
\hline 1 Propanol & 40.3 cde & $37.7 \mathrm{bcd}$ & $32.3 a b c$ & $30.7 \mathrm{ab}$ & $48.6 \mathrm{e}$ & $44.5 \mathrm{de}$ & $34.7 \mathrm{abc}$ & 41.4 cde & $32.3 \mathrm{abc}$ & $30.0 \mathrm{ab}$ & $26.7 \mathrm{a}$ & $28.1 \mathrm{a}$ \\
\hline 1 butanol & $1.06 \mathrm{bc}$ & $1.26 \mathrm{c}$ & $1.03 a b c$ & $0.92 \mathrm{abc}$ & $1.01 \mathrm{abc}$ & $1.00 \mathrm{abc}$ & $0.99 \mathrm{abc}$ & $1.04 \mathrm{abc}$ & $0.81 \mathrm{ab}$ & $0.87 \mathrm{ab}$ & $0.96 \mathrm{abc}$ & $\begin{array}{l}20.1 \mathrm{a} \\
0.69 \mathrm{a}\end{array}$ \\
\hline Isobutanol & $50.6 \mathrm{bc}$ & $45.1 \mathrm{abc}$ & $53.1 \mathrm{bc}$ & $47.8 \mathrm{abc}$ & $59.7 \mathrm{c}$ & $59.8 \mathrm{c}$ & $43.3 \mathrm{abc}$ & $44.5 \mathrm{abc}$ & $38.0 \mathrm{ab}$ & $36.6 \mathrm{ab}$ & $37.0 \mathrm{ab}$ & $31.5 \mathrm{a}$ \\
\hline 1 hexanol & $1.86 \mathrm{ab}$ & $1.78 \mathrm{ab}$ & $1.86 \mathrm{ab}$ & $1.57 \mathrm{ab}$ & $2.11 \mathrm{~b}$ & $1.93 \mathrm{ab}$ & $1.86 \mathrm{ab}$ & $1.97 \mathrm{ab}$ & $1.83 \mathrm{ab}$ & $1.56 \mathrm{ab}$ & $1.45 \mathrm{a}$ & $1.82 \mathrm{ab}$ \\
\hline Benzylic alcohol & $0.28 \mathrm{~b}$ & $0.27 \mathrm{ab}$ & $0.23 \mathrm{ab}$ & $0.26 \mathrm{ab}$ & $0.26 \mathrm{ab}$ & $0.23 \mathrm{ab}$ & $0.22 \mathrm{ab}$ & $0.18 \mathrm{a}$ & $0.19 \mathrm{ab}$ & $0.20 \mathrm{ab}$ & $0.24 \mathrm{ab}$ & $0.20 \mathrm{ab}$ \\
\hline Methionol & $4.44 \mathrm{e}$ & 3.49 cde & $4.03 \mathrm{de}$ & 3.40 bcde & $1.57 \mathrm{a}$ & $2.49 \mathrm{abcd}$ & $2.30 \mathrm{abcd}$ & $2.61 \mathrm{abcd}$ & $2.21 \mathrm{abc}$ & $1.75 \mathrm{abc}$ & $1.90 \mathrm{abc}$ & $1.72 \mathrm{ab}$ \\
\hline$\sum$ higher alcohols & $197 \mathrm{~d}$ & $171 \mathrm{bcd}$ & $158 \mathrm{abcd}$ & 149 abcd & $169 \mathrm{bcd}$ & $173 \mathrm{~cd}$ & $138 \mathrm{abc}$ & 154 abcd & $128 \mathrm{abc}$ & $119 \mathrm{ab}$ & $122 \mathrm{abc}$ & $112 \mathrm{a}$ \\
\hline Isoamyl acetate & $2.24 \mathrm{ab}$ & $1.56 \mathrm{ab}$ & $2.21 \mathrm{ab}$ & $1.79 \mathrm{ab}$ & $1.36 \mathrm{a}$ & $2.08 \mathrm{ab}$ & $2.14 \mathrm{ab}$ & $2.65 \mathrm{ab}$ & $2.55 \mathrm{ab}$ & $3.27 \mathrm{~b}$ & $2.50 \mathrm{ab}$ & $2.13 \mathrm{ab}$ \\
\hline 2 phenylethyl acetate & $0.30 \mathrm{bc}$ & $0.19 \mathrm{abc}$ & $0.17 \mathrm{ab}$ & $0.16 a b c$ & $0.14 \mathrm{a}$ & $0.22 \mathrm{abc}$ & $0.19 a b c$ & $0.25 \mathrm{abc}$ & $0.24 \mathrm{abc}$ & $0.33 \mathrm{c}$ & $0.19 \mathrm{abc}$ & $0.13 \mathrm{a}$ \\
\hline Ethyl propionate & $0.31 \mathrm{~d}$ & $0.26 \mathrm{~d}$ & $0.11 \mathrm{ab}$ & $0.10 \mathrm{ab}$ & $0.11 \mathrm{ab}$ & $0.14 \mathrm{bc}$ & $0.16 \mathrm{bc}$ & $0.18 \mathrm{c}$ & $0.12 \mathrm{abc}$ & $0.11 \mathrm{ab}$ & $0.10 \mathrm{ab}$ & $0.07 \mathrm{a}$ \\
\hline Octanoic acid & $1.47 \mathrm{abc}$ & $1.28 \mathrm{ab}$ & $2.04 \mathrm{abc}$ & $1.72 \mathrm{abc}$ & $0.88 \mathrm{a}$ & $1.37 \mathrm{abc}$ & $1.76 \mathrm{abc}$ & $1.75 \mathrm{abc}$ & $2.16 \mathrm{bc}$ & $2.55 \mathrm{bc}$ & $2.39 \mathrm{bc}$ & $2.57 \mathrm{c}$ \\
\hline Ethyl lactate & $1.65 \mathrm{ab}$ & $1.46 \mathrm{ab}$ & $2.65 \mathrm{bcd}$ & $2.50 \mathrm{bc}$ & $16.5 \mathrm{~g}$ & $10.6 \mathrm{f}$ & $4.25 \mathrm{e}$ & 3.88 cde & 2.83 bcde & 3.24 cde & $4.11 \mathrm{de}$ & $0.48 \mathrm{a}$ \\
\hline Acetoin & $9.84 \mathrm{~cd}$ & $11.3 \mathrm{~d}$ & $2.66 \mathrm{a}$ & $2.83 \mathrm{a}$ & $17.0 \mathrm{e}^{\mathrm{z}}$ & $15.6 \mathrm{e}$ & $8.75 \mathrm{~cd}$ & $7.55 \mathrm{bc}$ & $4.72 \mathrm{ab}$ & $3.93 \mathrm{a}$ & $4.30 \mathrm{ab}$ & $2.37 \mathrm{a}$ \\
\hline Dyacetil & $2.46 \mathrm{e}$ & $2.33 \mathrm{de}$ & $1.37 \mathrm{abc}$ & $1.12 \mathrm{abc}$ & $3.46 \mathrm{f}$ & $1.68 \mathrm{~cd}$ & $1.45 \mathrm{bc}$ & $1.11 \mathrm{abc}$ & $0.88 \mathrm{ab}$ & $0.83 \mathrm{ab}$ & $0.97 \mathrm{ab}$ & $0.69 \mathrm{a}$ \\
\hline Butirolactone & $1.78 \mathrm{c}$ & $1.57 \mathrm{abc}$ & $1.36 \mathrm{abc}$ & $1.18 \mathrm{a}$ & $1.62 \mathrm{abc}$ & $1.67 \mathrm{abc}$ & $1.58 \mathrm{abc}$ & $1.75 \mathrm{bc}$ & $1.52 \mathrm{abc}$ & $1.47 \mathrm{abc}$ & $1.40 \mathrm{abc}$ & $1.20 \mathrm{ab}$ \\
\hline
\end{tabular}

Different letters mean significant differences between species $(p \leq 0.05)$. 


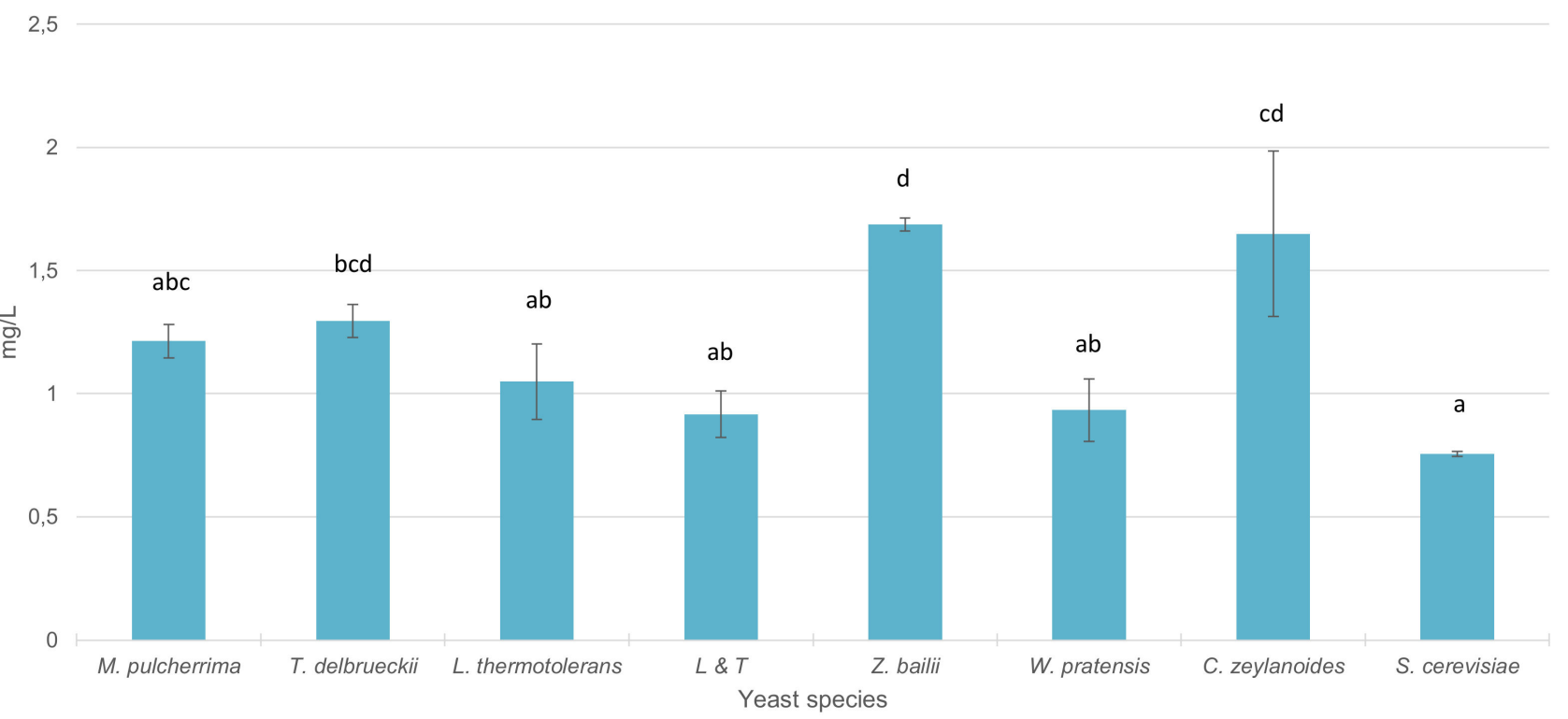

Figure 4. Total stilbene content (mg/L) in wines sequentially fermented with different yeast species. Different letters mean significant differences between the samples $(p \leq 0.05)$.

\section{Discussion}

\subsection{Clonal Characterization and $\mathrm{SO}_{2}$ Resistance}

A wide clonal diversity was found among the non-Saccharomyces isolates included in this work. As revealed in various studies, non-Saccharomyces yeasts show high intraspecific diversity, which involves the production of different enzymes and compounds during vinification, as well as different enological behavior $[28,33,63,64]$. This diversity was also reflected in the results obtained in $\mathrm{SO}_{2}$ resistance, which showed great differences between strains belonging to the same species. Growth respect to a control without $\mathrm{SO}_{2}$ was evaluated after 24 and $48 \mathrm{~h}$. Nevertheless, growth in the presence of $\mathrm{SO}_{2}$ at $24 \mathrm{~h}$ was taken into account as a selection criterion. Given the great competition between microorganisms that occurs in industrial vinifications, the ability to grow rapidly in the presence of $\mathrm{SO}_{2}$ represents an advantage for the yeast to establish itself in the medium. Results obtained at this stage confirm the importance of clonal characterization in the selection of yeasts for their use as inoculums in winemaking. For the following selection steps, representative clones were chosen and extremely sulfur sensitive strains were eliminated.

\subsection{Screening of Enzymatic Activities}

Among the enzymatic activities related to aroma, esterase and esterase-lipase were the most widespread activities and were found in strains of all the studied species. These activities are involved in the formation of esters, compounds that provide fruity aromas to wine. Results are in agreement with those obtained in the study carried out by Comitini et al. [7], in which the presence of esterase activity was observed in a large number of strains of different non-Saccharomyces yeast genera. On the other hand, in the present study, lipase activity was scarcely detected and only $33 \%$ of the S. salmonicolor strains and $12 \%$ of $L$. thermotolerans showed this activity. These enzymes cause the degradation of lipids, releasing fatty acids. Another activity that allowed the differentiation of the enzymatic profiles was $\beta$-glucosidase. This activity was more widespread in strains of Cryptococcus spp. and M. pulcherrima. Fernández et al. [65] indicated that $\beta$-glucosidase activity was mainly related to the species M. pulcherrima. Mendes Ferreira et al. [66] showed the potential of this species for the release of terpenes due to its high $\beta$-glucosidase activity, which coincides with the results obtained in the present work. 
Enzymatic profiles related to aroma shown in Table 1 within each species were mainly differentiated by esterase, esterase-lipase and $\beta$-glucosidase activities. For that reason, the strains that would be chosen based on their aromatic potential would be the ones included in the profiles that had all three enzymatic activities: CA5 of Candida spp., CCA1 of Cryptococcus spp., LA5 of L. thermotolerans, MA4 of M. pulcherrima and ZA3 of Z. bailii; and the ones included in the profiles with two of the activities: DA2 of D. hansenii, PKA1 of P. kluyveri, SPA2 of S. salmonicolor, TA5 of T. delbrueckii, WA1 of W. pratensis, and ZA5 of Z. bailii.

Concerning enzymatic activities related to color and fining, pectinase was the activity most detected within the group of carbohydrolases. In their study, Maturano et al. [67] found higher pectinase activity in T. delbrueckii compared to S. cerevisiae. Activities of the group of carbohydrolases favor the degradation of grape structural polysaccharides improving must extraction, clarification, wine filterability, and extraction of substances responsible for color and aroma during maceration [28]. The proteolytic enzymes aminopeptidases are involved in the reduction of proteic instability in wine [57]. Profiles that had more enzymatic activities related with color and limpidity of wine were: CC1 in Candida spp., CCC2 in Cryptococcus spp., DC2 in D. hansenii, LC6 in L. thermotolerans, MC4 and MC6 in M. pulcherrima, PKC1 in P. kluyveri, SPC1 in S. salmonicolor, TC4 and TC6 in T. delbrueckii, WC1 in W. pratensis and ZC1 in Z. bailii. Profile LC6 of L. thermotolerans showed all the carbohydrolase and aminopeptidase activities studied, which means great potential to improve wine characteristics.

All the strains previously indicated passed to the next selection stage due to their potential to improve the aroma, color, clarity and stability of red wines. Once the strains with the potential capacity to improve the characteristics of the wines had been chosen, their fermentative behavior under different conditions was studied.

4.3. Fermentative Behavior and Aromatic Compound Production of Non-Saccharomyces Strains in Pure 100 mL Vinifications

As expected, an increase in acidity levels was observed in wines inoculated with L. thermotolerans and Z. bailii. Other authors have described the production of lactic acid by $L$. thermotolerans [20], giving rise to $\mathrm{pH}$ drops and increases in total acidity values. Due to this feature, characteristic of $L$. thermotolerans, the use of this yeast in vinifications has been proposed as a tool to adjust the acidity of wines [20,68]. Regarding the increase in acidity levels in Z. bailii samples, it was related to the production of malic acid by this yeast. The production of this compound has been described by other authors in $Z$. rouxii [69]. The highest levels of glycerol were found in Z. bailii, followed by those detected in L. thermotolerans and M. pulcherrima, although differences were not significant respect to S. cerevisiae. This compound, which provides softness, sweetness and complexity to the wine, has been detected in higher concentrations in vinifications with non-Saccharomyces yeasts compared to S. cerevisiae [64]. Other authors have found a high production of glycerol in L. thermotolerans and C. zemplinina [70,71].

Analysis of aromatic composition showed interesting results in M. pulcherrima. This yeast produced high levels of higher alcohols and contributed positively to the aroma, since the concentration remained below $400 \mathrm{mg} / \mathrm{L}$, above which these compounds can cause organoleptic deviations. M. pulcherrima also showed the highest concentrations of 2phenylethanol and 2-phenyl acetate (data not shown). High production of 2-phenylethanol was found in M. pulcherrima in studies carried out by other authors [72-74]. Regarding production of esters, Rodríguez et al. [75] observed high concentrations of these compounds in M. pulcherrima. On the other hand, M. pulcherrima showed the highest levels of ethyl acetate, a compound that can give rise to off odors. These results are in agreement with those obtained in previous studies [11]. Besides, in wines inoculated with M. pulcherrima acetoin concentration exceeded the threshold above which unpleasant buttery aromas may appear.

The study of differences within clones of M. pulcherrima, T. delbrueckii and L. thermotolerans revealed variations in some important parameters such as volatile acidity, which can 
cause aromatic deviations in wine. In L. thermotolerans, clones were differentiated mainly by acidity parameters. Lactic acid production, a trait of great interest in this species, varied widely among the clones studied. Different studies have pointed out the importance of intraspecific heterogeneity in non-Saccharomyces yeasts [32,76,77].

\subsection{Influence of Sequential Inoculations with Non-Saccharomyces/S. cerevisiae on Wine Aroma and Composition of Anthocyans and Stilbenes in $2000 \mathrm{~mL}$ Vinifications}

The previous phases in the selection program showed that none of the non-Saccharomyces strains was able to complete fermentation. For that reason, sequential fermentations of the non-Saccharomyces strains with $S$. cerevisiae were performed in order to validate the behavior of these non-Saccharomyces in the conditions in which they will be used.

The enological parameters studied showed higher glycerol levels in wines sequentially inoculated with M. pulcherrima, T. delbrueckii and the two mixed inocula compared to those inoculated only with $S$. cerevisiae (data not shown). Previous studies have shown the ability of different non-Saccharomyces yeasts to produce high concentrations of glycerol $[64,70,71]$.

Aromatic compound analysis revealed a differentiation of samples inoculated with $T$. delbrueckii and L. thermotolerans. Wines sequentially inoculated with these yeasts showed an increase in the concentration of higher alcohols compared to those fermented only with S. cerevisiae. As occurred in the previous stage, the levels remained below the concentration limit that can cause aromatic deviations. In T. delbrueckii and one of the L. thermotolerans strains (L54) the highest levels of diacetyl were detected. This compound can give rise to unpleasant buttery aromas in wine that are detected when the concentration reaches the threshold value of $8 \mathrm{mg} / \mathrm{L}$ [61]. Diacetyl levels remained below this threshold value in all samples. On the other hand, acetoin showed the highest values in L. thermotolerans, but they also remained below the threshold value. In wines sequentially inoculated with L. thermotolerans concentrations of ethyl lactate were significantly higher than those found in wines inoculated only with $S$. cerevisiae and inoculated with other non-Saccharomyces yeasts. In their study, Del Fresno et al. [78] only detected ethyl lactate in fermentations with L. thermotolerans, which is explained by the ability of this yeast to produce lactic acid and the dependence of ethyl lactate formation on the levels of lactic acid present in the medium. As can be observed, T. delbrueckii and L. thermotolerans, the two species that remained the longest in the tanks, showed the most notable differences in the aromatic profile. These results highlight the importance of the implantation ability of the selected inoculum to achieve the modulation of the characteristics of the wine.

Regarding parameters related with wine color, total anthocyan content was significantly higher than that observed for wines inoculated only with S. cerevisiae in M. pulcherrima, T. delbrueckii, Z. bailii and C. zeylanoides. In their work, Chen et al. [79] observed higher concentration of total anthocyanins in sequential fermentations with M. pulcherrima and T. delbrueckii compared to fermentations carried out only with $S$. cerevisiae. On the other hand, Belda et al. [80] noticed increases in color intensity and total polyphenol index (TPI) in mixed fermentations with $M$. pulcherrima compared to fermentations only with $S$. cerevisiae.

Total stilbene content showed higher values in vinifications sequentially inoculated with non-Saccharomyces yeasts respect to those found in vinifications inoculated only with S. cerevisiae, and differences were significant in C. zeylanoides, Z. bailii and T. delbrueckii. Several studies have shown the influence that different yeast strains can have on stilbene levels in wine $[81,82]$. The presence of enzymatic activities such as $\beta$-glucosidase can influence the resveratrol content. Gaensly et al. [83] observed that yeast strains with this enzymatic activity favored the hydrolysis of the transpiceid into trans-resveratrol.

\subsection{Selection of the Inoculum for Red Winemaking}

The review of the characteristics observed during the selection program in M. pulcherrima and the mixed inoculum L. thermotolerans/T. delbrueckii was conducted in order to choose the most suitable option for its use in winemaking. The high implantation and the ability to remain in the tanks for a longer time of the mixed inoculum L. thermotolerans / T. delbrueckii were important features to be taken into account in an inoculum intended for 
its use in industrial vinifications. On the other hand, the release by the two species of the mixed inoculum of compounds that improve the quality of the wine, such as glycerol and lactic acid, was another important criterion in the selection. The previous results, coupled to the fact that there is no inoculum on the market composed of these two nonSaccharomyces species together, led to the decision to select the mixed inoculum composed of T. delbrueckii and L. thermotolerans (70/30) for its use in winemaking in order to improve the characteristics of red wines.

\section{Conclusions}

This study shows the different steps carried out for the selection of a non-Saccharomyces yeast inoculum from the Rioja winegrowing region. Some advantages over fermentations performed only with $S$. cerevisiae have been proven, which demonstrates the potential of non-Saccharomyces yeasts for use as inocula in winemaking. Differences in important parameters such as $\mathrm{SO}_{2}$ resistance, enzymatic activities or production of compounds have been observed between strains, highlighting the relevance of clonal screening in selection processes. On the other hand, during the development of the selection program it is important to consider the type of wine yeasts are destined to produce and the specific characteristics that want to be modulated in order to choose the most suitable inoculum. Taking into account all the mentioned points, the mixed inoculum of L. thermotolerans / $T$. delbrueckii was selected in the final stage for its use in winemaking. Given its characteristics, such as the high implantation capacity, the production of compounds of interest and the modulation of wine acidity, this inoculum is suitable for the production of quality wines.

Supplementary Materials: The following are available online at https: / www.mdpi.com/article/ 10.3390/fermentation7030148/s1, Table S1: Yeast isolates of each species and place of isolation, Table S2: Percentage (\%) of strains growing at the same level as control at $48 \mathrm{~h}$ after inoculation, with different dosages of $\mathrm{SO}_{2}$, Table S3: Maximum level of $\mathrm{SO}_{2}$ which allowed a similar growth to control at $24 \mathrm{~h}$ and enzymatic activities of the twenty-four strains selected for the vinification trials, Table S4: Average oenological traits of wines (with significant differences) fermented by different Lachancea thermotolerans (Lt) strains and statistical analysis, Table S5: Analytical parameters (mg/L) with significant differences produced by different non-Saccharomyces yeasts at the end of alcoholic fermentation.

Author Contributions: R.E.-V. was in charge of the methodology and the original draft preparation. L.G.-A. and P.G. were also responsible of the methodology. R.L. and P.S. researched and were in charge of resources. A.R.G. was responsible for the project administration, and developed the formal analysis, resources and reviewed and edited the draft. All authors have read and agreed to the published version of the manuscript.

Funding: This research was funded by Instituto Nacional de Investigaciones Agrarias (INIA) (Project RTA2013-0053-C03).

Institutional Review Board Statement: Not applicable.

Informed Consent Statement: Not applicable.

Data Availability Statement: Not applicable.

Conflicts of Interest: The authors declare no conflict of interest.

\section{References}

1. Varela, C.; Siebert, T.; Cozzolino, D.; Rose, L.; McLean, H.; Henschke, P.A. Discovering a chemical basis for differentiating wines made by fermentation with "wild" indigenous and inoculated yeasts: Role of yeast volatile compounds. Aust. J. Grape Wine Res. 2009, 15, 238-248. [CrossRef]

2. Romano, P.; Capece, A.; Jespersen, L. Taxonomic and Ecological Diversity of Food and Beverage Yeasts; Springer: Berlin/Heidelberg, Germany, 2006; ISBN 4535283230.

3. Rainieri, S.; Pretorius, I.S. Selection and improvement of wine yeasts. Ann. Microbiol. 2000, 50, $15-31$.

4. Romano, P.; Fiore, C.; Paraggio, M.; Caruso, M.; Capece, A. Function of yeast species and strains in wine flavour. Int. J. Food Microbiol. 2003, 86, 169-180. [CrossRef] 
5. Jolly, N.P.; Augustyn, O.P.H.; Pretorius, I.S. The Role and Use of Non-Saccharomyces Yeasts in Wine Production. S. Afr. J. Enol. Vitic. 2006, 27, 15-39. [CrossRef]

6. Rojas, V.; Gil, J.V.; Piñaga, F.; Manzanares, P. Acetate ester formation in wine by mixed cultures in laboratory fermentations. Int. J. Food Microbiol. 2003, 86, 181-188. [CrossRef]

7. Comitini, F.; Gobbi, M.; Domizio, P.; Romani, C.; Lencioni, L.; Mannazzu, I.; Ciani, M. Selected non-Saccharomyces wine yeasts in controlled multistarter fermentations with Saccharomyces cerevisiae. Food Microbiol. 2011, 28, 873-882. [CrossRef]

8. Benito, S.; Hofmann, T.; Laier, M.; Lochbühler, B.; Schüttler, A.; Ebert, K.; Fritsch, S.; Röcker, J.; Rauhut, D. Effect on quality and composition of Riesling wines fermented by sequential inoculation with non-Saccharomyces and Saccharomyces Cerevisiae. Eur. Food Res. Technol. 2015, 241, 707-717. [CrossRef]

9. Ciani, M.; Comitini, F.; Mannazzu, I.; Domizio, P. Controlled mixed culture fermentation: A new perspective on the use of non-Saccharomyces yeasts in winemaking. FEMS Yeast Res. 2010, 10, 123-133. [CrossRef]

10. Lambrechts, M.G.; Pretorius, I.S. Yeast and its Importance to Wine Aroma-A Review. S. Afr. J. Enol. Vitic. 2000, 21, 97-129. [CrossRef]

11. Liu, J.; Arneborg, N.; Toldam-Andersen, T.B.; Zhang, S.; Petersen, M.A.; Bredie, W.L.P. Impact of sequential co-culture fermentations on flavour characters of Solaris wines. Eur. Food Res. Technol. 2017, 243, 437-445. [CrossRef]

12. Loira, I.; Morata, A.; Comuzzo, P.; Callejo, M.J.; González, C.; Calderón, F.; Suárez-Lepe, J.A. Use of Schizosaccharomyces pombe and Torulaspora delbrueckii strains in mixed and sequential fermentations to improve red wine sensory quality. Food Res. Int. 2015, 76, 325-333. [CrossRef] [PubMed]

13. Medina, K.; Boido, E.; Fariña, L.; Gioia, O.; Gomez, M.E.; Barquet, M.; Gaggero, C.; Dellacassa, E.; Carrau, F. Increased flavour diversity of Chardonnay wines by spontaneous fermentation and co-fermentation with Hanseniaspora vineae. Food Chem. 2013, 141, 2513-2521. [CrossRef]

14. Bely, M.; Stoeckle, P.; Masneuf-Pomarède, I.; Dubourdieu, D. Impact of mixed Torulaspora delbrueckii-Saccharomyces cerevisiae culture on high-sugar fermentation. Int. J. Food Microbiol. 2008, 122, 312-320. [CrossRef] [PubMed]

15. Belda, I.; Navascués, E.; Marquina, D.; Santos, A.; Calderon, F.; Benito, S. Dynamic analysis of physiological properties of Torulaspora delbrueckii in wine fermentations and its incidence on wine quality. Appl. Microbiol. Biotechnol. 2015, 99, 1911-1922. [CrossRef]

16. Renault, P.; Coulon, J.; de Revel, G.; Barbe, J.C.; Bely, M. Increase of fruity aroma during mixed T. delbrueckii/S. cerevisiae wine fermentation is linked to specific esters enhancement. Int. J. Food Microbiol. 2015, 207, 40-48. [CrossRef]

17. Azzolini, M.; Tosi, E.; Lorenzini, M.; Finato, F.; Zapparoli, G. Contribution to the aroma of white wines by controlled Torulaspora delbrueckii cultures in association with Saccharomyces cerevisiae. World J. Microbiol. Biotechnol. 2015, 31, 277-293. [CrossRef] [PubMed]

18. Belda, I.; Ruiz, J.; Beisert, B.; Navascués, E.; Marquina, D.; Calderón, F.; Rauhut, D.; Benito, S.; Santos, A. Influence of Torulaspora delbrueckii in varietal thiol (3-SH and 4-MSP) release in wine sequential fermentations. Int. J. Food Microbiol. 2017, 257, 183-191. [CrossRef]

19. Kapsopoulou, K.; Mourtzini, A.; Anthoulas, M.; Nerantzis, E. Biological acidification during grape must fermentation using mixed cultures of Kluyveromyces thermotolerans and Saccharomyces cerevisiae. World J. Microbiol. Biotechnol. 2007, 23, 735-739. [CrossRef]

20. Gobbi, M.; Comitini, F.; Domizio, P.; Romani, C.; Lencioni, L.; Mannazzu, I.; Ciani, M. Lachancea thermotolerans and Saccharomyces cerevisiae in simultaneous and sequential co-fermentation: A strategy to enhance acidity and improve the overall quality of wine. Food Microbiol. 2013, 33, 271-281. [CrossRef]

21. Vilela, A. Lachancea thermotolerans, the Non-Saccharomyces yeast that reduces the volatile acidity of wines. Fermentation 2018, 4 , 56. [CrossRef]

22. Hranilovic, A.; Gambetta, J.M.; Schmidtke, L.; Boss, P.K.; Grbin, P.R.; Masneuf-Pomarede, I.; Bely, M.; Albertin, W.; Jiranek, V. Oenological traits of Lachancea thermotolerans show signs of domestication and allopatric differentiation. Sci. Rep. 2018, 8, 1-13. [CrossRef]

23. Ciani, M.; Beco, L.; Comitini, F. Fermentation behaviour and metabolic interactions of multistarter wine yeast fermentations. Int. J. Food Microbiol. 2006, 108, 239-245. [CrossRef]

24. Divol, B.; Du Toit, M.; Duckitt, E. Surviving in the presence of sulphur dioxide: Strategies developed by wine yeasts. Appl. Microbiol. Biotechnol. 2012, 95, 601-613. [CrossRef] [PubMed]

25. Krieger, S. Application of yeast and bacteria as starter cultures. In Biology of Microorganisms on Grapes, in Must and in Wine; König, H., Unden, G.F., Eds.; Springer: Berlin/Heidelberg, Germany, 2017; pp. 605-634.

26. Fernández-González, M.; Di Stefano, R.; Briones, A. Hydrolysis and transformation of terpene glycosides from muscat must by different yeast species terpene glycosides from muscat. Food Microbiol. 2003, 20, 35-41. [CrossRef]

27. Zoecklein, B.W.; Marcy, J.E.; Williams, J.M.; Jasinski, Y. Effect of native yeasts and selected strains of Saccharomyces cerevisiae on glycosyl glucose, potential volatile terpenes, and selected aglycones of White Riesling (Vitis vinifera L.) wines. J. Food Compos. Anal. 1997, 10, 55-65. [CrossRef]

28. Strauss, M.L.A.; Jolly, N.P.; Lambrechts, M.G.; Van Rensburg, P. Screening for the production of extracellular hydrolytic enzymes by non-Saccharomyces wine yeasts. J. Appl. Microbiol. 2001, 91, 182-190. [CrossRef] 
29. Sumby, K.M.; Grbin, P.R.; Jiranek, V. Microbial modulation of aromatic esters in wine: Current knowledge and future prospects. Food Chem. 2010, 121, 1-16. [CrossRef]

30. Nieuwoudt, H.H.; Prior, B.A.; Pretorius, L.S.; Bauer, F.F. Glycerol in South African Table Wines: An Assessment of its Relationship to Wine Quality. S. Afr. J. Enol. Vitic. 2017, 23, 22-30. [CrossRef]

31. Aranda, A.; Matallana, E.; del Olmo, M. Levaduras. Saccharomyces I. Levaduras de primera fermentación. In Microbiología del Vino; Carrascosa, A.V., Muñoz, R., González, R., Eds.; AMV Ediciones: Madrid, Spain, 2005; pp. 273-297.

32. Renault, P.; Miot-Sertier, C.; Marullo, P.; Hernández-Orte, P.; Lagarrigue, L.; Lonvaud-Funel, A.; Bely, M. Genetic characterization and phenotypic variability in Torulaspora delbrueckii species: Potential applications in the wine industry. Int. J. Food Microbiol. 2009, 134, 201-210. [CrossRef] [PubMed]

33. Zott, K.; Thibon, C.; Bely, M.; Lonvaud-Funel, A.; Dubourdieu, D.; Masneuf-Pomarede, I. The grape must non-Saccharomyces microbial community: Impact on volatile thiol release. Int. J. Food Microbiol. 2011, 151, 210-215. [CrossRef] [PubMed]

34. Schvarczová, E.; Štefániková, J.; Jankura, E.; Kolek, E. Selection of autochthonous Saccharomyces cerevisiae strains for production of typical Pinot Gris wines. J. Food Nutr. Res. 2017, 56, 389-397.

35. Querol, A.; Huerta, T.; Barrio, E.; Ramón, D. Dry Yeast Strain For Use in Fermentation of Alicante Wines: Selection and DNA Patterns. J. Food Sci. 1992, 57, 183-185. [CrossRef]

36. Rodríguez, M.E.; Infante, J.J.; Molina, M.; Domínguez, M.; Rebordinos, L.; Cantoral, J.M. Genomic characterization and selection of wine yeast to conduct industrial fermentations of a white wine produced in a SW Spain winery. J. Appl. Microbiol. 2010, 108, 1292-1302. [CrossRef]

37. Bae, S.; Fleet, G.H.; Heard, G.M. Lactic acid bacteria associated with wine grapes from several Australian vineyards. J. Appl. Microbiol. 2006, 100, 712-727. [CrossRef]

38. Lopes, C.A.; Rodríguez, M.E.; Sangorrín, M.; Querol, A.; Caballero, A.C. Patagonian wines: The selection of an indigenous yeast starter. J. Ind. Microbiol. Biotechnol. 2007, 34, 539-546. [CrossRef] [PubMed]

39. Tristezza, M.; Fantastico, L.; Vetrano, C.; Bleve, G.; Corallo, D.; Mita, G.; Grieco, F. Molecular and technological characterization of Saccharomyces cerevisiae strains isolated from natural fermentation of susumaniello grape must in Apulia, Southern Italy. Int. J. Microbiol. 2014, 2014, 897428. [CrossRef] [PubMed]

40. Ocón, E.; Garijo, P.; Sanz, S.; Olarte, C.; López, R.; Santamaría, P.; Gutiérrez, A.R. Screening of yeast mycoflora in winery air samples and their risk of wine contamination. Food Control 2013, 34, 261-267. [CrossRef]

41. Ocón, E.; Gutiérrez, A.R.; Garijo, P.; Tenorio, C.; López, I.; López, R.; Santamaría, P. Quantitative and qualitative analysis of non-Saccharomyces yeasts in spontaneous alcoholic fermentations. Eur. Food Res. Technol. 2010, 230, 885-891. [CrossRef]

42. Ocón, E.; Gutiérrez, A.R.; Garijo, P.; López, R.; Santamaría, P. Presence of non-Saccharomyces yeasts in cellar equipment and grape juice during harvest time. Food Microbiol. 2010, 27, 1023-1027. [CrossRef]

43. González-Arenzana, L.; Garijo, P.; Berlanas, C.; López-Alfaro, I.; López, R.; Santamaría, P.; Gutiérrez, A.R. Genetic and phenotypic intraspecific variability of non-Saccharomyces yeasts populations from La Rioja winegrowing region (Spain). J. Appl. Microbiol. 2017, 122, 378-388. [CrossRef]

44. Escribano, R.; González-Arenzana, L.; Garijo, P.; Berlanas, C.; López-Alfaro, I.; López, R.; Gutiérrez, A.R.; Santamaría, P. Screening of enzymatic activities within different enological non-Saccharomyces yeasts. J. Food Sci. Technol. 2017, 54, 1555-1564. [CrossRef]

45. Sampaio, T.L.; Kennedy, J.A.; Vasconcelos, M.C. Use of microscale fermentations in grape and wine research. Am. J. Enol. Vitic. 2007, 58, 534-539.

46. López, I.; Torres, C.; Ruiz-Larrea, F. Genetic typification by pulsed-field gel electrophoresis (PFGE) and randomly amplified polymorphic DNA (RAPD) of wild Lactobacillus plantarum and Oenococcus oeni wine strains. Eur. Food Res. Technol. 2008, 227, 547-555. [CrossRef]

47. Kurtzman, C.; Fell, J.W. The Yeasts: A Taxonomic Study, 4th ed.; Elsevier Science: Amsterdam, The Netherlands, 1998.

48. Commission Regulation. Laying Down Certain Detailed Rules for Implementing Council Regulation (EC) No 479/2008 as Regards the Categories of Grapevine Products, Oenological Practices and the Applicable Restrictions; (EC) No 606/2009 of 10 July 2009 ; European Comission: Brussels, Belgium, 2009; pp. 1-59.

49. Somers, T.C.; Evans, M.E. Wine quality: Correlations with colour density and anthocyanin equilibria in a group of young red wines. J. Sci. Food Agric. 1974, 25, 1369-1379. [CrossRef]

50. Ortega, C.; López, R.; Cacho, J.; Ferreira, V. Fast analysis of important wine volatile compounds. J. Chromatogr. A 2001, 923, 205-214. [CrossRef]

51. López, R.; López-Alfaro, I.; Gutiérrez, A.R.; Tenorio, C.; Garijo, P.; González-Arenzana, L.; Santamaría, P. Malolactic fermentation of Tempranillo wine: Contribution of the lactic acid bacteria inoculation to sensory quality and chemical composition. Int. J. Food Sci. Technol. 2011, 46, 2373-2381. [CrossRef]

52. Portu, J.; López-Alfaro, I.; Gómez-Alonso, S.; López, R.; Garde-Cerdán, T. Changes on grape phenolic composition induced by grapevine foliar applications of phenylalanine and urea. Food Chem. 2015, 180, 171-180. [CrossRef]

53. Portu, J.; López, R.; Ewald, P.; Santamaría, P.; Winterhalter, P.; Garde-Cerdán, T. Evaluation of Grenache, Graciano and Tempranillo grape stilbene content after field applications of elicitors and nitrogen compounds. J. Sci. Food Agric. 2018, 98, 1856-1862. [CrossRef] [PubMed] 
54. Gutiérrez, A.R.; Santamaría, P.; González-Arenzana, L.; Garijo, M.P.; Berlanas, C.; López-Alfaro, I.; López, R. SO 2 tolerance in non-Saccharomyces yeasts. In Proceedings of the 39th World Congress of Vine and Wine, Bento Gonçalves, Brazil, 24-28 October 2016.

55. Trinh, T.T.T.; Woon, W.Y.; Yu, B.; Curran, P.; Liu, S.Q. Effect of L-isoleucine and L-phenylalanine addition on aroma compound formation during longan juice fermentation by a co-culture of Saccharomyces cerevisiae and Williopsis saturnus. S. Afr. J. Enol. Vitic. 2010, 31, 116-124. [CrossRef]

56. Santamaría, P.; López, R.; Portu, J.; González-Arenzana, L.; López-Alfaro, I.; Gutiérrez, A.R.; Garde-Cerdán, T. Role of phenylalanine in viticulture and enology. In Phenylalanine. Dietary, Sources, Functions and Health Effects; Elliamson, D., Ed.; Nova Publisher: New York, NY, USA, 2015; pp. 49-70.

57. Dizy, M.; Bisson, L.F. Proteolytic activity of yeast strains during grape juice fermentation. Am. J. Enol. Vitic. 2000, 51, 155-167.

58. Escribano, R.; González-Arenzana, L.; Portu, J.; Garijo, P.; López-Alfaro, I.; López, R.; Santamaría, P.; Gutiérrez, A.R. Wine aromatic compound production and fermentative behaviour within different non-Saccharomyces species and clones. J. Appl. Microbiol. 2018, 124, 1521-1531. [CrossRef] [PubMed]

59. Rapp, A.; Versini, G. Influence of nitrogen compounds in grapes on aroma compounds of wines. Dev. Food Sci. 1995, 37, 1659-1694. [CrossRef]

60. Ribéreau-Gayon, P.; Dubourdieu, D.; Donèche, B.; Lonvaud-Funel, A. Handbook of Enology; John Willey and Son: West Sussex, UK, 2007; Volume 2.

61. Romano, P.; Suzzi, G. Origin and production of acetoin during wine yeast fermentation. Appl. Environ. Microbiol. 1996, 62, 309-315. [CrossRef] [PubMed]

62. Escribano-Viana, R.; González-Arenzana, L.; Portu, J.; Garijo, P.; López-Alfaro, I.; López, R.; Santamaría, P.; Gutiérrez, A.R. Wine aroma evolution throughout alcoholic fermentation sequentially inoculated with non- Saccharomyces/Saccharomyces yeasts. Food Res. Int. 2018, 112, 17-24. [CrossRef]

63. Capece, A.; Fiore, C.; Maraz, A.; Romano, P. Molecular and technological approaches to evaluate strain biodiversity in Hanseniaspora uvarum of wine origin. J. Appl. Microbiol. 2005, 98, 136-144. [CrossRef] [PubMed]

64. Rossouw, D.; Bauer, F.F. Exploring the phenotypic space of non-Saccharomyces wine yeast biodiversity. Food Microbiol. 2016, 55, 32-46. [CrossRef]

65. Fernández, M.; Úbeda, J.F.; Briones, A.I. Typing of non-Saccharomyces yeasts with enzymatic activities of interest in wine-making. Int. J. Food Microbiol. 2000, 59, 29-36. [CrossRef]

66. Ferreira, A.M.; Clímaco, M.C.; Faia, A.M. The role of non-Saccharomyces species in releasing glycosidic bound fraction of grape aroma components-A preliminary study. J. Appl. Microbiol. 2001, 91, 67-71. [CrossRef]

67. Maturano, Y.P.; Rodríguez Assaf, L.A.; Toro, M.E.; Nally, M.C.; Vallejo, M.; Castellanos de Figueroa, L.I.; Combina, M.; Vazquez, F. Multi-enzyme production by pure and mixed cultures of Saccharomyces and non-Saccharomyces yeasts during wine fermentation. Int. J. Food Microbiol. 2012, 155, 43-50. [CrossRef]

68. Benito, Á.; Calderón, F.; Palomero, F.; Benito, S. Combine use of selected Schizosaccharomyces pombe and Lachancea thermotolerans yeast strains as an alternative to the traditional malolactic fermentation in red wine production. Molecules 2015, 20, 9510-9523. [CrossRef]

69. Taing, O.; Taing, K. Production of malic and succinic acids by sugar-tolerant yeast Zygosaccharomyces rouxii. Eur. Food Res. Technol. 2007, 224, 343-347. [CrossRef]

70. Jolly, N.P.; Varela, C.; Pretorius, I.S. Not your ordinary yeast: Non-Saccharomyces yeasts in wine production uncovered. FEMS Yeast Res. 2014, 14, 215-237. [CrossRef] [PubMed]

71. Masneuf-Pomarede, I.; Bely, M.; Marullo, P.; Albertin, W. The genetics of non-conventional wine yeasts: Current knowledge and future challenges. Front. Microbiol. 2016, 6. [CrossRef]

72. Clemente-Jimenez, J.M.; Mingorance-Cazorla, L.; Martínez-Rodríguez, S.; Las Heras-Vázquez, F.J.; Rodríguez-Vico, F. Molecular characterization and oenological properties of wine yeasts isolated during spontaneous fermentation of six varieties of grape must. Food Microbiol. 2004, 21, 149-155. [CrossRef]

73. Padilla, B.; Gil, J.V.; Manzanares, P. Past and future of non-Saccharomyces yeasts: From spoilage microorganisms to biotechnological tools for improving wine aroma complexity. Front. Microbiol. 2016, 7, 1-20. [CrossRef]

74. Prior, K.J.; Bauer, F.F.; Divol, B. The utilisation of nitrogenous compounds by commercial non-Saccharomyces yeasts associated with wine. Food Microbiol. 2019, 79, 75-84. [CrossRef]

75. Rodríguez, M.E.; Lopes, C.A.; Barbagelata, R.J.; Barda, N.B.; Caballero, A.C. Influence of Candida pulcherrima Patagonian strain on alcoholic fermentation behaviour and wine aroma. Int. J. Food Microbiol. 2010, 138, 19-25. [CrossRef]

76. Ciani, M.; Maccarelli, F. Oenological properties of non-Saccharomyces yeasts associated with wine-making. World J. Microbiol. Biotechnol. 1998, 14, 199-203. [CrossRef]

77. van Breda, V.; Jolly, N.; van Wyk, J. Characterisation of commercial and natural Torulaspora delbrueckii wine yeast strains. Int. J. Food Microbiol. 2013, 163, 80-88. [CrossRef]

78. Del Fresno, J.M.; Morata, A.; Loira, I.; Bañuelos, M.A.; Escott, C.; Benito, S.; González Chamorro, C.; Suárez-Lepe, J.A. Use of non-Saccharomyces in single-culture, mixed and sequential fermentation to improve red wine quality. Eur. Food Res. Technol. 2017, 243, 2175-2185. [CrossRef] 
79. Chen, K.; Escott, C.; Loira, I.; del Fresno, J.M.; Morata, A.; Tesfaye, W.; Calderon, F.; Suárez-Lepe, J.A.; Han, S.; Benito, S. Use of non-Saccharomyces yeasts and oenological tannin in red winemaking: Influence on colour, aroma and sensorial properties of young wines. Food Microbiol. 2018, 69, 51-63. [CrossRef] [PubMed]

80. Belda, I.; Conchillo, L.B.; Ruiz, J.; Navascués, E.; Marquina, D.; Santos, A. Selection and use of pectinolytic yeasts for improving clarification and phenolic extraction in winemaking. Int. J. Food Microbiol. 2016, 223, 1-8. [CrossRef] [PubMed]

81. Clare, S.S.; Skurray, G.R.; Shalliker, R.A. Effect of yeast strain selection on the concentration of cis- and trans-resveratrol and resveratrol glucoside isomers in wine. Aust. J. Grape Wine Res. 2005, 11, 9-14. [CrossRef]

82. Kostadinović, S.; Wilkens, A.; Stefova, M.; Ivanova, V.; Vojnoski, B.; Mirhosseini, H.; Winterhalter, P. Stilbene levels and antioxidant activity of Vranec and Merlot wines from Macedonia: Effect of variety and enological practices. Food Chem. 2012, 135, 3003-3009. [CrossRef]

83. Gaensly, F.; Agustini, B.C.; da Silva, G.A.; Picheth, G.; Bonfim, T.M.B. Autochthonous yeasts with $\beta$-glucosidase activity increase resveratrol concentration during the alcoholic fermentation of Vitis labrusca grape must. J. Funct. Foods 2015, 19, $288-295$. [CrossRef] 